\title{
CrimRxiv
}

\section{The Growth of}

\section{Incarceration in the United}

States: Exploring Causes

\section{and Consequences}

National Research Council

Published on: Mar 06, 2022

DOI: $10.21428 / c b 6 a b 371 . a 8 d 1 f 5 b 7$

License: Creative Commons Attribution 4.0 International License (CC-BY 4.0). 
